\title{
Chapter 6 \\ Intergenerational Relationships in Migrant \\ Families. Theoretical and Methodological \\ Issues
}

Claudine Attias-Donfut and Joanne Cook

\subsection{Introduction}

Migration has become a family based project, whether it involves the migration of the whole family, the formation of family post-migration or the financial support of family in the country of origin. The growing tendency of migrants to settle permanently rather than to practice circular migrations raises new challenges, not only for migration policy but also for integration patterns and for family policy and practices. We are convinced that a generational approach is one of the most inspiring ways to explore such questions.

Migration experiences are indeed very different from one generation to another and they often exacerbate generational differences. Therefore it is necessary to develop studies to identify changes from one generation to the other within migrant families and to examine the impact of migration on the relationships between generations. This chapter is focused on theoretical and methodological issues through the presentation of studies investigating these generational changes, and combining several methods, using quantitative, qualitative and comparative data. We will first summarize some of the main results relating to the topic, on the basis of the literature and on studies that we have carried out at a national and cross-national level.

The family is increasingly understood as pivotal to migration, forming the central consideration in the majority of decisions to relocate and proving fundamental to shaping transitions to settlement (Knack and Settles Nauck and Settles 2001).

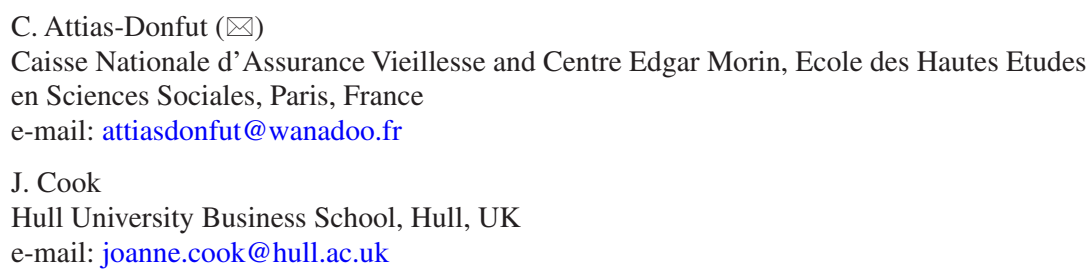


Despite this recognition research on migrant families has been slow to emerge. The past decade has witnessed a growth in interest on migrant families in both research and policy arenas. While generational transitions can prove problematic postmigration, as parents and children adapt to the new country at differing rates, research and policy has been overly concentrated on the divides this creates and has, consequently, problematized migrants families as traditional and resistant to integration (Waite and Cook 2011; Foner and Dreby 2011; Kofman 2004). The findings discussed in this chapter are rooted in more nuanced and complex understanding of migrant families. It frames migrant families as fluid structures of intergenerational adaptation, renegotiation and change, and capable of supporting the transition of both parent and child generations as well as at times sites of conflict and contestation (Foner 1997, 2009; Creese et al. 1999; Creese 2011; Kofman 2004).

Let's first begin by a short presentation of two of these studies. The first one was conducted in France on a large sample of ageing migrants coming from all continents (PRI Survey). The second one is a comparative research conducted in Britain, France and South Africa which explores the migration experiences of African families across two generations.

\subsection{Description of Immigrants and Retirement Survey}

The Immigrants and Retirement Survey (Enquête sur le Passage à la Retraite des Immigrés - PRI) on immigrants' experience of ageing and retirement in France was conducted between November 2002 and February 2003 on the immigrant population aged 45-70 residing in France, as defined by place of birth (outside France) and nationality of birth (non-French), which includes people who have acquired French citizenship by naturalization but excludes French citizens by birth who were born in other countries. ${ }^{1}$ The Immigrants and Retirement Survey differs from most other surveys of immigration, which focus on the issue of integration, because the main purpose was to study immigrants' transition from work to retirement and record their life, migration, occupational and family histories. The survey contains information about the respondents' socio-demographic and economic characteristics, their family circles and social networks, as well as economic assistance and transfers they receive and provide. It also deals with plans for retirement, including intentions about future country of residence. Lastly, it studies the respondents' living conditions at retirement, opinions of retirement, changing inter-generational relationships and attitudes to the host country and home country. The survey includes data on religion and religiosity, which is rare in studies conducted in France

\footnotetext{
${ }^{1}$ Algerians born during the period of French colonization who opted for Algerian citizenship after independence were included in the sample, whereas French citizens born in Algeria, "pieds-noirs", were not surveyed.
} 
and is therefore worthy of note. The survey covered the 12 regions of mainland France, where $90 \%$ of the total target population lives. ${ }^{2}$

The choice of the 45-70 age group targets the life stages of maturity and retirement. It makes it possible to study cohorts from waves of migration with specific profiles and origins at a precise period in recent migration history, namely the 1960s, which saw the largest inflow of migrants in the history of France. To ensure that the sample contained an optimum number of migrants from the most significant flows, the age structure of people from the different groups of countries was taken into account. The lower age limit of 45 enabled nationals from sub-Saharan and North Africa to be included. The upper age limit was set at 70 to balance the sample, avoiding over-representation of Italians and Spaniards and under-representation of Africans and Asians.

The sample is large enough to allow specific studies of immigrants from three southern European countries (Italy, Portugal and Spain) and three North African countries (Algeria, Morocco and Tunisia). Some overall conclusions can be drawn for immigrants from Turkey. Other countries are grouped into broadly homogeneous geographical regions.

Albeit the data are cross-sectional, they offer several interesting features when focusing on the motives for private transfers to children. First, there are questions about the provision of transfers made during the last 5 years and parents indicate whether they have helped each of their children. Second, parents provide the main characteristics of the children. The information on the child generation given by parents presents specific advantages: First all of the siblings of the same family are described, which allow the comparison between them. For example, the gender differences are more obvious. This method also gives access to a phenomenon which is difficult to observe: how many children were left behind, what are their characteristics and their situation in the country of origin. We can also get information about children who left the host country to migrate to another country or to return to the country of origin. Although the level of income of the children remains unknown, the survey includes a measure of the children's financial position (through a qualitative evaluation by parents, see Attias-Donfut and Wolff 2008).

\subsection{Qualitative and Comparative Study}

The second comparative study on migration and intergenerational relations among African migrants was conducted in France, Britain and South Africa, during 20082010.The objectives of the study were to compare experiences of African migrants living in different socio-political contexts, to illuminate the ways that regional and

\footnotetext{
${ }^{2}$ The sample was obtained by random sampling performed by Insee on the basis of the population census of 1999, 12,000 "address files" were selected. The data were collected by INSEE surveyors through face-to-face interviews lasting approximately $90 \mathrm{~min}$, using a questionnaire on a laptop computer (CAPI). The final sample consists of 6211 people living in ordinary households.
} 
national contexts shape migration experiences. This research compares how different post-colonial/post-Apartheid histories and policies of migration shape the experiences and lives of older African migrants and their children. One of the main questions is focused on citizenship and belonging: How do generational dynamics intersect with the construction (and change) of different realms of belonging.

\subsubsection{Research Methods of the Comparative Study}

The qualitative research methods included focus groups with African migrants (organized according to gender, age and community), and biographical interviews with two family members across parent and child generations. The interviews were also followed up by a short face to face demographic questionnaire. The research was carried out by three research teams who worked collectively to develop comparative research tools, fieldwork and analysis. All three studies adopted the same methodological tools (interview guides) and also carried out key informant interviews with policy makers at the national and local levels, as well as interviews with migrant community representatives.

Each study was funded independently; the French Study was funded by the CNAV, the British by the British Academy and the South African by the North-West University.

The populations examined in these studies are drawn from African nationalities which have a historical relationship with the three countries of study. Very little comparative research exists that examines African migration and intergenerational relationships across European and African contexts (See Creese 2011; Foner and Dreby 2011). Thus the primary focus of this study was to examine the migration experiences of a much under-researched Diaspora, that of African families who have settled in three distinct countries with different post-colonial histories and structures. There are important insights to be gleamed from a focus on the African Diaspora's experiences of integration into the different cultural spaces with their own colonial histories of inclusion and exclusion. This is not to underplay the importance of ethnic differences within the Diaspora but this was not the primary aim of the comparative elements of the projects. For the British and French studies the populations are drawn from former colonies or protectorate African countries. The South African study focuses upon countries that have traditionally been a source of migrant labor and supportive in the anti-Apartheid struggle, namely Botswana, Malawi, Mozambique and Zimbabwe.

Designing qualitative comparative methodologies across three countries is inevitably a complex process, which necessitates compromises and flexibility in design to accommodate national contexts and socio-cultural differences. While sample sizes differed across the three studies due to variations in funding (Table 6.1), each study applied the same research methods, interview tools and sample criteria. That is each project sought to recruit families where at least two generations were willing to take part in individual biographical interviews, where the family had been settled 
Table 6.1 Participants' number by country

\begin{tabular}{l|l|l|l}
\hline Country & No. of focus groups & No. of families & Total bi-generational interviews \\
\hline France & 4 & 24 & 56 \\
\hline Britain & 8 & 20 & 40 \\
\hline South Africa & 4 & 10 & 20 \\
\hline
\end{tabular}

in the new country for at least 2 years, and where the second generation were aged 15 and over. The recruitment methods varied across the three studies, in the UK ethnic community associations and migrant support organizations were used to recruit participants. In France and South Africa recruitment was organized through a combination of community organizations and individual snow balling. Some of the participants in focus groups also took part in the bi-generational family interviews but the focus groups were also used to gather additional experiences from other families who did not take part in the biographical phases.

Overall the three studies included over 200 participants in the bi-generational interviews and focus groups.

The socio-economic settings of these three studies were all large scale cities experiencing varying degrees of economic prosperity and restructuring. Two of the cities were capitals; Pretoria and Paris, and the two regional economic centers of Leeds and Johannesburg and two sizable regional cities of Sheffield and Grenoble. Altogether the research spanned six cities which have been long established destinations for African migration.

The results have been published in Attias-Donfut et al. (Eds.) (2012b). The impact of migration across generations is a core theme running throughout this book and the chapters examine the impact of migration on the transmission of family practices, culture and tradition across generations, alongside the evolution of familial intergenerational relationships post-migration.

The comparative analysis is located around three core themes, citizenship, belonging and intergenerational relations. By drawing upon these three analytical foundations it is possible to examine familial, state and societal structures as both enabling and disabling systems which shape the citizenship and lived experiences of African migrants and their post-migration sense of belonging.

\subsection{Theoretical and Empirical Issues on Migrant Intergenerational Relationships}

Two main opposing propositions have been set up to describe family changes following migration. On the one hand family cohesion is assumed to be higher in immigrant families as compared to non-migrant families in the receiving countries. On the other hand, the second proposition suggests greater family disintegration and alienation or conflict due to the contradiction between traditional family values and individualization as proposed by modernization theory. 
In fact, neither of these propositions has been really validated so far. According to several studies, there is no evidence of significant differences between migrants and non-migrants in the level of solidarity or conflict (see, for example, Bolzman et al. 2006 for Switzerland and Baykara-Krumme 2008 for Germany, among others).

As a family project, migration involves all family generations linked by a complex set of gifts, debts and reciprocity. Help given to parents, including financial transfers, as well as other forms of help, is part of a gift contract. In addition, conflicts and solidarity are not incompatible with each other, and the notion of ambivalent relationships, developed by Lüscher and Lettke (2008), is applicable both to migrant and non-migrant families. Thus, rather than a fracturing of intergenerational relations post-migration research has revealed complex processes of renegotiation that take place in migrant families that involve restructuring, contestation, compromise and in some circumstances conflict (Foner 1997; Creese et al. 1999; Kofman 2004). These approaches reveal the fluid nature of migrant families and the complex renegotiations that take place across both generations to ensure the successful settlement of the family in a new land.

Inevitably migration brings specific changes in the functioning of families following migration. These include: (a) The contraction around nuclear family relations; (b) the central positions taken by the children; (c) the changes in gender relations; and (d) the transfer behaviors of migrants; (e) the intergenerational social mobility.

(a) The contraction around nuclear family relations is common to many migrants from different countries. It is reinforced by the political and legal difficulties that family members encounter when joining their families in the new country. Sometimes conflicts between parents and children are related to the consequences of having been absent from their everyday life for a long period. This is an example of what Colen (1995) named 'stratified reproduction' to describe social inequality in child rearing. In addition, bringing up children without the support of the extended family is a challenge for many migrants, mainly for African migrants who are used to sharing the responsibility of the children with the extended family and neighbors (Journet and Julliard 1994; Itzigsohn and Giorguli-Saucedo 2005).

The loss of extended family networks in everyday practices was a recurring theme in the comparative study. For example, parents in all three countries spoke of the challenge of bringing up children without the support of the extended family, and the incongruence between practices in their country of origin where bringing up children was a 'shared project' in which all adults played a role. This placed a heavy burden on parents and particularly upon the women in these families who were no longer able to share the child care across generations. However the research also found that despite the distancing of extended family relations the central importance of the family group remained, and was upheld through the transmission of the bonds between the generations which continued to operate transnationally. 
(b) The family project is being reconstructed mainly around the central positions taken by children, who have the moral obligation to socially succeed in the host country, as a return gift, to repay for parents' and grandparents" "sacrifices", and to contribute to taking care of family members (Attias-Donfut and Waite 2012). This explains the strong motivations transmitted by migrants to their children to succeed at school. Further children often play an important role as helpers at a younger age than in non-migrant families. Since they have a better knowledge of the language and of the social codes than their parents, they are able to serve as mediators between them and the social environment. This can result in a kind of inversion of the respective positions of parents and children in family responsibilities. In the comparative study high educational values and a drive for the child generation's success were prominent in all the African families across the three countries. Education was seen as the key route to social mobility for the family as a whole. The upward mobility of the child generation through educational success were strong values held by the parent generation, emphasized through transmission and symbolized by the investment of resources to ensure their children could reap the benefits of migration. However there are some cases of painful failures. For example, in the French sample some parents left quite good employment positions in Africa, in order to set up a better business in France, but they did not succeed. They could not go back home, because they would have lost face, and they are obliged to stay and live in a downwardly mobile position in France (Attias-Donfut et al. 2012a).

(c) Changes in gender relations - these are closely linked to changes in intergenerational relations, both resulting in a decrease in traditional familial patriarchal norms. Women experience a process of "liberation" in the host country, since they benefit from the relaxation of gender divisions. In addition, more and more women are playing an increasingly important role in financially supporting their families post-migration. Female migration can be seen in some cases as a process of migrant women empowerment (Foner 1997). The move to a new society has exacerbated gender changes for many of these families (Itzigsohn and Giorguli-Saucedo 2005; Hansen 2008), especially since women are playing an increasingly important role in financially supporting their families postmigration (Kofman and Meetoo 2008). Migration may be experienced as a liberating process when it serves as a way to escape from a controlling, hostile and violent social environment. Marital conflicts existing prior to migration may be one of the reasons for the decision to migrate (Araujo 2009). More generally we observe that at the time of retirement, women are less willing than men to return to the country of origin, they are reluctant to play a traditional role again back in their home country.

Shifts in gender hierarchies were identified across the British, French and South African samples in the comparative study. This is reflected in the high incidence of single parent families in the French and British studies, and of female migrants moving with one or more child leaving their husbands behind to look after younger children as is evident in the South African study. The transformation of gender relations within African migrant families is further 
shaped by the integration of the child generations into French, British and South African society, where the opportunities available to women are different to those on offer to their mother's generation in their country of origin. Sometimes these transformations in gender relations were resisted and in a minority of cases they led to family break-off. But what the intergenerational perspective of this study reveals is that for both generations migration afforded family members with a degree of agency over what they chose to transmit to the next generation and for many families this involved opening educational opportunities and greater freedoms to their daughters. A process that seemed to increase as the generations passed (Attias-Donfut et al. 2012a).

In intergenerational relations, religious references are important, especially among Muslim families which represent an important and growing part of immigrants in Europe (much more than in the U.S.). Parents come from patriarchal families where the notion of respect is omnipresent and dialogue is absent, especially on topics linked to sexual life. Children have to perpetuate cultural and religious traditions; women must marry a Muslim partner and not have sexual relations outside marriage. In France, the majority of marriages of second-generation Muslim migrants are endogamous, some being arranged by parents, others being negotiated between parents and children, and around $2 \%$ are forced marriages (which are illegal of course). Mixed marriages, which represent a minority, sometimes lead to a generational break-off. However, while parental control over children works during the premarital period, it does not work anymore in the conjugal life of children. The latter become more individualized and they progressively adopt the values of their peer group in general society. They adopt norms of education less oriented toward the transmission of the tradition and more toward child development, and as time passes, migrant children are moving away from religious observance (Collet and Santelli 2012).

(d) Financial transfers among migrants' families. With the circulation of human beings, there is an increasing circulation of financial capital. Remittances nowadays represent a considerable amount of money. The economic stakes involved in these international flows are huge, both at the macro and micro-level of the functioning of the families involved. Money sent by migrants may, to a great extent, improve the standard of living of the family left behind. This also has an impact on the receiving countries, as migrants reduce their standard of living and consume less in the host country because they devote a part of their revenue to their families in the countries of origin. At the macroeconomic level, remittances affect the economic growth of origin countries as well as the brain drain from those countries (Beine et al. 2008). Despite the importance of this phenomenon, the transfer behaviors of migrants living in Europe have not been sufficiently studied. We lack data on this topic as on many other questions related to migration.

We hypothesize that migrants' attitudes and decisions regarding financial transfers are different from those of the general population, based on four reasons (Attias-Donfut and Wolff 2008). First, family structures vary according to the country of origin. Fertility rates are still high in some developing countries, resulting in large extended families, including many siblings. The family soli- 
darity network size is essential for the functioning of transfers, large families providing multiple opportunities and obligations to help and get support. Second, migrants often belong to a 'transnational family', part of it being located in the country of origin, part of it being in the country of residence. This concerns particularly the first generation of immigrants. Consequently, they are submitted to two distinct pressures: from the family in the country of residence and from the family left behind. Some migrants have children both in the host country and in the country of origin. In other cases, parents and siblings are still in the home country, while spouse and children live in their new place of residence. In such a configuration, we can expect the existence of a double channel of transfers, one directly linked to migration through the return of money to the country of origin and another one circulating between family members living in the new country.

Thirdly, the level of responsibilities towards either parents or children is deeply shaped by the social benefits available to family members in the country where they live. Consequently, they are expected to vary a lot according to migratory waves and the origins of the migrants. The level of social welfare in the country of origin directly impacts the financial transfer behavior of migrants. Therefore, we do not expect to find among them the same transfer decisions as in the general population of the host country. Lastly, these differences in transfer behaviors are not only due to economic and political, but also to cultural factors (Antonucci and Jackson 2003).

According to the PRI data, we find that migrants are mainly givers. They give much more and more frequently than they receive. The proportion of respondents claiming that they have made cash gifts or loans during the last 5 years amounts to $38.6 \%$, but only $6.2 \%$ of them report having received some money. This difference may be due to the fact that migrants have higher wages in the host country with respect to the other family members. They may also have received, at an earlier date, money from the family, before the migration, and now have to honor their debt. The structure of their solidarity network is less exclusively focused on the intergenerational line, compared to what we already know about the general population in France (see Attias-Donfut and Arber 2000). There are also significant exchanges with siblings (8.5\%) and to a lesser extent with non family members $(4.8 \%){ }^{3}$

When considering the direction of money given, we find that parents are more frequently receivers than children. The frequency of gifts to children is $14.4 \%$, while it is $17.7 \%$ for gifts to parents. In comparison to family transfers among natives in France, the importance of ascending transfers is the main characteristic of migrants' behavior (Attias-Donfut 1995; Kohli 1999). As shown in Fig. 6.1, those who give to elderly parents are mainly coming from developing countries where retirement systems are scarce or absent. While about $2-3 \%$ of the respondents send money to their parents in Italy or Spain, this proportion amounts to $30.5 \%$ for migrants born in Morocco and to $29 \%$ for migrants born in Tunisia. The main givers to parents are mostly coming from

\footnotetext{
${ }^{3}$ We note that non-family members are more frequently involved in money lending than in money giving.
} 


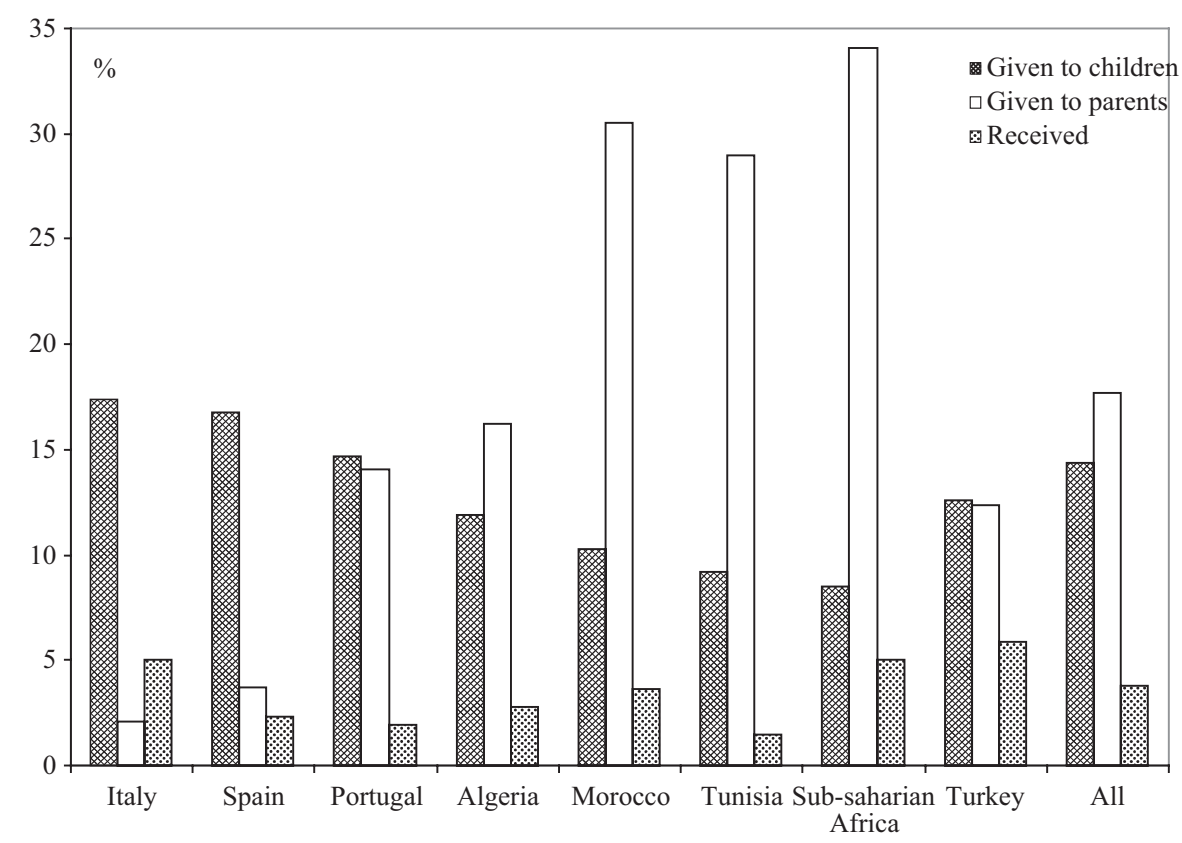

Fig. 6.1 The pattern of family financial transfers, by country of origin (PRI survey 2003)

Maghreb, Sub-Saharan Africa and to a lesser extent from Portugal. Money given by migrants to parents plays the role of old age insurance.

Conversely, migrants coming from Northern Europe have the same pattern of transfers as the general French population, i.e. essentially large cash gifts made to children and very few ascending financial transfers. These European countries are all welfare societies, though their welfare systems have different levels of generosity. This result confirms the role played by pension systems in shaping modern family transfers. The implementation of old age pensions has changed the circulation of private economic support, henceforth directed toward children and no longer toward parents. The development of the welfare state has thus resulted in an inversion of the direction of transfers. The downward direction of transfers is now generalized in Europe, regardless of the level of generosity of the welfare state.

While the settlement of migrants tends to become permanent, especially among migrants who have had long stays in the host country, capital partly flows from the host country to Country of Origin, thus establishing an invisible and strong bridge between two distinct worlds, that of emigration and immigration. This financial help compensates for the lack of care in the form of time transfers, due to geographical distance.

But do ageing migrants in host countries receive more family care than the non-migrant elderly? Contrary to a popular belief, this is not the case. Elderly migrants, like non-migrants, need complementary care from public services and they are not reluctant to get professional help when they need it. Where elderly 
migrants have less recourse to professional services this may be due to their lack of information, lack of support structures to enable access or because they do not dare to assert their rights. More information and more professional training are needed to facilitate the delivery of public support to older migrants.

Indeed the comparative study confirmed the welfare mix that older migrants had opted for post-migration with many of them retaining their preference to be cared for in extended family networks but at the same time reflecting upon what they could realistically expect from their children. Consequently, the African parent generations were accepting of the need to either agree to a mixture of state and family care in later life or they had made plans to return home in later life to be cared for and play a senior role in their extended family and community networks in their country of origin (Attias-Donfut et al. 2012a).

(e) Intergenerational social mobility. The main route for success is education. And it works: Whatever the country of origin, the great majority of the children are doing better than their parents, despite less favorable conditions compared with the native population. Among the second generation, school performance is quite high, mainly among girls, who succeed better than boys on average in all migrant groups (Attias-Donfut and Wolff 2009). This result is usually underestimated by researchers when they compare the second generation to their peers in the native population regardless of the social position of the family. The tendency is rather to emphasize the position of migrants as 'dominated' people, in the line of Bourdieu's 'domination theory' (Sayad 1999). According to our results the great majority of migrants consider themselves as having climbed the social scale relative to their parents, and they think that their children are again doing better than themselves. The minority which considers itself in social descent is overrepresented among African migrants. African migrants in France as well as in the UK and in the U.S. include a high proportion of people with a high level of education. An important brain drain characterizes African migration waves. The United Nations (2004) reports that on average, migrants from Africa have had schooling that is three times as long as the average national population at the migrants' destination. Especially in Europe, there is an underutilization of their skills and qualifications resulting in a loss of human capital.

\subsection{Identity Transmission and Reconstruction from One Generation to the Other}

Finally, what is crucially at stake among generations of immigrants is not so much the functioning of solidarity nor the affective bonds, which are usually maintained and sometimes reinforced, but rather the questions related to the transmission of values, norms, family and collective memory, involving personal and social identity and the sense of belonging. 
Migrant families frequently retain ties to their country of origin while simultaneously settling in their country of migration. Migrants, being 'here and there', belong at least to two places. This dual attachment has produced an abundant literature on the notions of identity, belonging, and citizenship. Belonging is commonly described with regard to a 'sense of belonging', an exploration of 'feelings of being in place'. The emotional aspects of belonging are at the core of this definition. 'Belonging should be seen as an emotionally constructed category' (British Home Office report 2008). It is different from ethnic identity, which in turn is not static and fixed but is constantly re-constructed in relation to the social and political environment and in relation to citizenship. Citizenship too is evolving in relation to migration and to the meaning given to national identity. The idea of 'postnational citizenship' (Soysal 1994), was followed by a recognition of 'transnational citizenship'. Plurilocal attachments are compatible with simultaneous national belonging. However, since 9/11, we are witnessing a resurgence of citizenship, in nation-states: Citizenship is becoming conditional on fulfilling multiple rules and conditions and increasingly linked to 'belonging'. The states are concerned about national identity and social cohesion linked to questions of security in migration policies. There are different realms of belonging: sense, everyday practices, and formal structures (e.g. citizenship).

Civic stratification, a concept which we owe to Lockwood (1996), and which was developed more deeply by Morris (2002) seems to be useful to understand some generational dynamics in immigrant families. It is a form of inequality which crosscuts ethnic, geographical or socio-economic inequality. This concept refers to the system of rights granted to the immigrants, which forms a hierarchy just like the social hierarchy and in interaction with it. Such a system exists everywhere but its shape and the strength of its constraints vary according to the national migratory policies.

The position of migrants in civic stratification can be different from one generation to the other. For example a child born in the host country may have a higher position and/or more civic rights than his/her parents who were born outside the country. Citizenship and belonging are evolving from one generation to the next. Many parents express strong attachment to their country of origin, but they rarely can transmit this attachment to their children who belong more to the new country, which is generally their birth country. When children visit their parents' country of origin, some are not close to it and may feel like foreigners. Very few would like to live there, as shown in all studies. The majority has complex attachment to both places. There is a generational discontinuity between first and second generation in most domains: socio-economic milieu, belonging, citizenship, language, way of life, women's roles, values... The generational chain has been interrupted; there is no more reproduction from one generation to the next, but rather an unchaining process which favors the membership in the new society.

In our comparative study on African migrant families, we found in the second generation a deep desire to integrate in all of the three different migration regimes, more assimilationists in France, more multicultural in Britain, and despite the lack of rights and discrimination met in post-apartheid South Africa. The pulling power of the current social environment seems more decisive than family legacy. But the problem is acceptance by the host country. As Anthias (2006) says, "To belong is to 
be accepted as part of a community". Some of the second generation find obstacles to integration because of persistent messages of exclusion, difficulties getting a job, living in poor urban sections. Or they are attracted by other identifications, ethnicities, religion or political values, which may be a reaction to the feeling of exclusion. Religious belonging creates a space for the construction of an identity that transcends state borders. As analyzed by Glick Schiller and Çaglar (2008), belonging to transnational networks brings a feeling of empowerment by the strength of network ties as well as the belief system. This is facilitated by the internet which is, mainly for the younger generation, a new public sphere for the expression of citizenship, be it local, national or global.

While the first generation seems more respectful of social order and established institutions, the second generation is more demanding. Immigrant children, at least some of them, are struggling for the right to be different without compromising the right to belong. These demands concern mainly the field of religion. Being more integrated into the society, they are also more willing to protest, to be politically involved, and to exert an influence to bring changes so that their host countries become effectively plural.

In France, according to our results, feelings of discrimination are increasing from the first to the second generation. One of the reasons may be that migrant children have more interaction with others and the native population, another reason are their greater demands and their frustration for not being recognized as full members of the society. The same results are found in the survey done in Clichy-Montfermeil, the suburb where the 2005 riots took place and which has been completely renovated since these events (Kepel 2011).

\subsection{Transmigration and Ageing}

A key theme running throughout the migration literature is the emergence of transmigration and processes of 'circulation' or 'comings and goings' between the new country and the country of origin. Several studies point out an increase in the 'circulation of children' between migrant parents and grandparents in the country of origin $(\mathrm{CoO})$. Alongside this process there has been a growth in older generations engaging in transmigration as a way of living across two locations rather than engaging in permanent return (Attias-Donfut 2006; Bolzman et al. 2004). Transnationalist practices are expressed in several ways, among them, remittances (see above), visits to $\mathrm{CoO}$, the desire to return, or the imaginary return to ancestors through repatriation to the bodies to be buried in the $\mathrm{CoO}$.

The nostalgic dream of return to an idealized homeland remains a strong narrative in the lives of first generation residents; its presence shapes family life influencing experiences of settlement and belonging as well as structuring transmission and relations across generations (Wessendorf 2007; Maynard et al. 2008; Levitt 2009; King et al. 2011). The dream of returning to life as it once was in the country of origin sustains migrant families through the difficult times of settling and adapt- 
ing to a new country (Ganga 2006). While the desire to return is often overstated in the literature, with many immigrants settling permanently in the country of migration, the exploration of and the desire to return remain on the agenda in many families (Waite and Cook 2011; Attias-Donfut et al. 2012a). Turning this dream into a reality comes to the fore for first generation migrants as they approach retirement. Many of them have to make a decision: to settle permanently in host country, to return to the $\mathrm{CoO}$, or to engage in transmigration (to come and go between the two countries).

The comparative study found that the project of return was stronger amongst the parent than the child generation but that some children also shared the desire to live in their parent homeland in the future. In addition the desire to return was more frequently present in the narrative of the families residing in South Africa and Britain than it was in the French sample. This related to the migration routes (with a larger proportion in the British sample that had been forced to migrate due to civil war). Similarly the families living in South Africa were more likely to see their migration as temporary and the reunification with their families in the homeland as the end result (Attias-Donfut et al. 2012a). Despite these differences the project of return evolved within the African families out of a balancing of the needs of the whole family (child education, elder care etc.) As a consequence, some first generation migrants let go of their dream of return in order to retain close proximity to their children and grandchildren. For a small minority in our sample, transmigration was viewed as a realistic compromise. Living across the two countries was portrayed as a way of holding onto the dream of return particularly within the French and British studies.

The PRI survey results show that only a small percentage of migrants choose to return to their $\mathrm{CoO}$ : $7 \%$ on average, ranging from 2\% among the Algerians to $17 \%$ among the Sub-Sahara Africans (Fig. 6.2).

The significant variables characterizing the minority who choose to return are the following:

- Gender: more men than women

- Family bonds: Having children in home country and no child in France

- Family bonds: Having siblings in home country and no siblings in France

- Health: those in rather good health

- Ownership: those having no ownership in France

- Age of migration: having migrated late in life

- Citizenship: no French citizen

- Country of origin: coming more often from Portugal or Sub-Sahara Africa

One of the most fundamental factors shaping the decision to engage in return migration is the location of children, with parents overwhelmingly opting to live near to where their children reside. In this sense decisions about return are shaped by the needs of all of the family members. Key influences include the location of family members, economic resources (housing), health condition and cultural identification. The decision to remain, return or engage in transmigration for first generation migrants depends on the specific manner in which they combine personal 


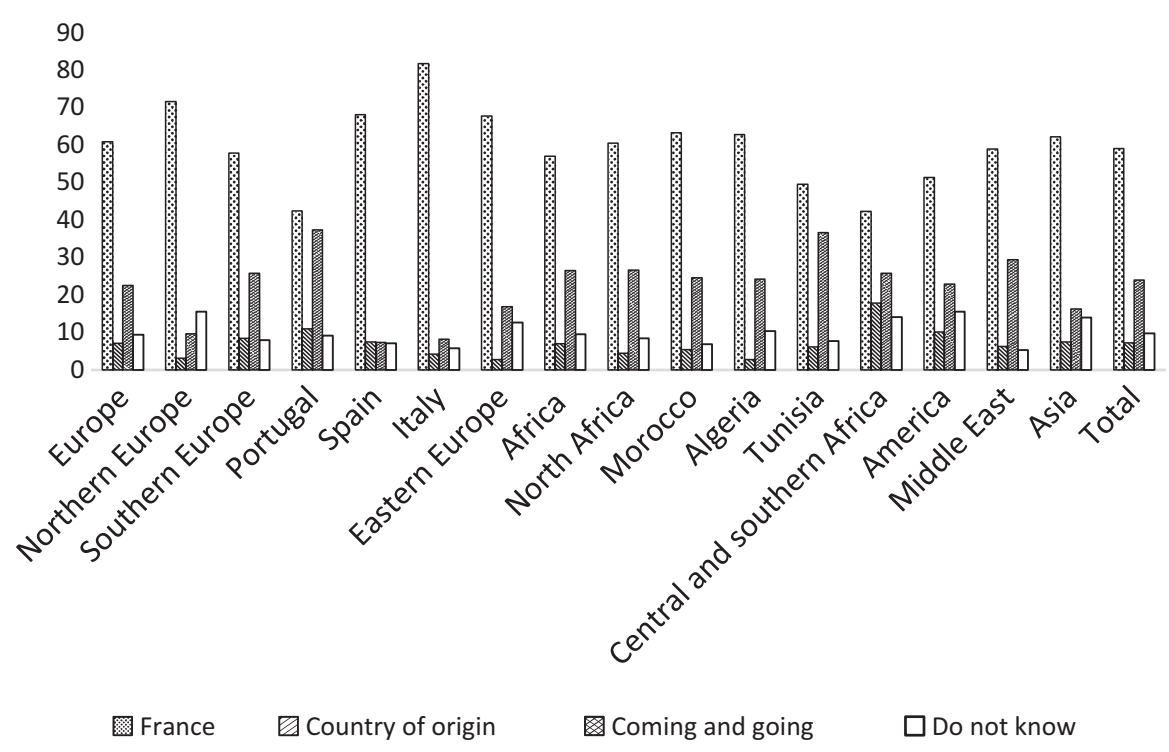

Fig. 6.2 Life choice for retirement by country (in \%) (PRI survey 2003)

resources and cultural identity (Bolzman et al. 2004). For those who opt for transmigration both countries have acquired personal meaning so they 'come and go' between the two. However, it is important to recognize that the option to engage in transmigration is not open for everyone since it requires significant economic resources. Thus for those with financial difficulties the tendency to settle permanently is much higher, especially if they do not own property in the country of origin. For the majority who decide to remain this involves letting go of the dream of return for at least the foreseeable future. Moreover, the socialization of the child and, to some extent, also parent generations into the culture and society of their host country can lead migrants to feel like foreigners upon return. Consequently the desire to return may become less appealing once it is translated into reality.

There is also an imaginary return post mortem. The choice to end one's life in the host country can be associated with the decision to be buried in the home country. The PRI study reveals a strong preference for burial in the home country among persons from Africa and from Muslim countries. 68.2\% of migrants from Turkey, $58.5 \%$ of those coming from North Africa and $44.5 \%$ of those coming from SubSaharan Africa want to be buried in their country of origin, while this desire is only expressed by less than $12 \%$ of those coming from Asia or European countries. The Portuguese represent an exception, with $34.4 \%$ wanting to be buried in Portugal.

There are again several variables which influence this choice. Women prefer to be buried in France more often than men, mainly in order to have their grave visited by children. Family geography has a strong influence: when their parents are buried in France, or when they live there, the migrants always prefer to be buried in France. 
Table 6.2 Burial location preferences of migrants according to their country of origin (in \%) (PRI Survey 2003)

\begin{tabular}{l|l|l}
\hline & France & Country of origin \\
\hline Europe C\&N & 56.7 & 10.7 \\
\hline Portugal & 31.5 & 34.4 \\
\hline Spain & 66.3 & 12.1 \\
\hline Italy & 76.8 & 8.1 \\
\hline Maghreb & 23.0 & 58.5 \\
\hline $\begin{array}{l}\text { Africa } \\
\text { Sub-Saharian }\end{array}$ & 27.2 & 44.5 \\
\hline Turkey & 20.0 & 68.2 \\
\hline Asia & 62.4 & 12.1 \\
\hline
\end{tabular}

This appears to be an important factor in the assertion of the feeling of belonging to France. It shows the symbolic power of death rituals among the migrant population (Table 6.2).

The choice of burial place is thus founded upon a sense of belonging to a territory, a group or a family network, but it also raises a 'generational dilemma:

Migration is liable to introduce spatial discontinuity between the place where people are buried (in the home country) and the place where they live, thereby breaking the territorial link in the chain of generations. The only two options are to break with the dead or to break with the living. Burial in the country of adoption consecrates the break with the past and with the dead, forcing those who make this choice to abandon any hope of joining the chain of generations, though it preserves their chances of being remembered by the living and hence their survival by proxy. Conversely, being laid to rest with one's ancestors as a mark of loyalty to family history may cut individuals off from the living generations, those of the future, and compromise their chances of survival by proxy, since their graves are likely to be abandoned by the living. So migrants whose offspring have settled in France may thus face a dilemma (Attias-Donfut and Wolff 2005: 702).

\subsection{Conclusions}

Migration sheds a specific light on the life course and the relationship between generations, and the process of ageing. It poses at the same time new policy challenges that are still unrecognized in many countries. As has been shown in this chapter, the core of the migration experience is the reshaping of life courses and intergenerational relationships and the restructuring of family life in a new socio-cultural setting. The chapter has highlighted several gaps in existing research which if addressed could offer significant insights for research and policy. Key areas include the need for more research examining financial transfer/remittance behaviors of migrants living in Europe. Money transfers have great consequences not only on the bonds between the two countries, but also on living standards and social mobility of successive generations. Growing older in the country of migration involves a complex welfare mix which is shaped by what migrant parents can realistically expect from their children alongside unequal degrees of access to welfare and professional 
services. While many migrants assert their preference to be cared for in extended family networks more information and more professional training are needed to facilitate the delivery of public support to older migrants. Historically, research and policy has been preoccupied with conflict in intergenerational relations, while not denying the challenges migration poses for intergenerational relations, this chapter has highlighted the need for policy and research to develop a greater focus on the renegotiation and adaptation of intergenerational relationships and expectations across generations and genders. Familial expectations are being renegotiated not just by the resistance and renegotiation of child generations but also by the new gender freedoms of mothers (and some fathers) who are key to extending these transformations across the generations. Finally this chapter has highlighted some of the core challenges facing Immigrant children around their claiming of citizenship and belonging in the new country. It has pointed to how some of the child generation are struggling for the right to be different without compromising the right to belong. These claims are particularly pertinent in the emerging tensions around migration surfacing across Europe. Importantly this chapter has argued how research around the citizenship and belonging of migrants can inform policy and help negotiate a more inclusive citizenship settlement for migrant generations.

Despite their importance for the understanding of the evolution of modern states, such topics are still under-researched and remain either misunderstood in social policy or entirely excluded. Intercultural and intergenerational research is needed, including two or three family generations across countries and across continents. The studies presented in this chapter bring methodological advances in this respect, showing the importance of combining several methodological approaches in order to understand the passing of generations across countries. This research would throw greater light on the impact of migration on the bonds and support that passes between family generations as well as generating greater understanding of the role families play in the settlement of the next generations.

Acknowledgments This paper benefited from the support of the Swiss National Centre of Competence in Research LIVES-Overcoming Vulnerability: Life Course Perspectives, which is financed by the Swiss National Science Foundation (Grant number: 51NF40-160590).

\section{References}

Anthias, F. (2006). Belongings in a globalizing and unequal world: Rethinking translocations. In N. Yuval-Davis, K. Kannabiran, \& U. Vieten (Eds.), The situated politics of belonging (pp. 17-31). London: Sage.

Antonucci, T. C., \& Jackson, J. S. (2003). Ethnic and cultural differences in intergenerational social support. In V. L. Bengtson \& A. Lowenstein (Eds.), Global ageing and challenge to families (pp. 355-370). New York: Aldine de Gruyter.

Attias-Donfut, C. (Ed.). (1995). Les Solidarités entre Générations. Paris: Armand Colin.

Attias-Donfut, C. (Ed.). (2006). L'enracinement. Enquête sur le vieillissement des immigrés en France. Paris: Armand Colin. 
Attias-Donfut, C., \& Arber, S. (2000). Equity and solidarity across the generations. In S. Arber, \& C. Attias-Donfut (Eds.), The myth of generational conflict. Family and the State in an aging Society (pp. 1-21). London: Routledge.

Attias-Donfut, C., \& Waite, L. (2012). From generation to generation: Changing family relations, citizenship and belonging. In C. Attias-Donfut, J. Cook, J. Hoffman, \& L. Waite (Eds.), Citizenship, belonging and intergenerational relations in African migration (pp. 40-62). London: Palgrave MacMillan.

Attias-Donfut, C., \& Wolff, F. C. (2005). The preferred burial locations of persons born outside France. Population English Edition, 60(5-6), 813-836.

Attias-Donfut, C., \& Wolff, F. C. (2008). Patterns of intergenerational transfers among immigrants in France and families in Europe. In C. Saraceno (Ed.), Families, ageing and social policy (pp. 259-284). Cheltenham: Edward Elgar.

Attias-Donfut, C., \& Wolff, F. C. (2009). Le destin des enfants d'immigrés. Paris: Stock.

Attias-Donfut, C., Cook, J., \& Hoffman, J. (2012a). Understanding African migration: Intergenerational relations, citizenship and belonging in a comparative context. In C. AttiasDonfut, J. Cook, J. Hoffman, \& L. Waite (Eds.), Citizenship, belonging and intergenerational relations in African migration (pp. 165-188). London: Palgrave MacMillan.

Attias-Donfut, C., Cook, J., Hoffman, J., \& Waite, L. (Eds.). (2012b). Citizenship, belonging and intergenerational relations in African migration. London: Palgrave MacMillan.

Baykara-Krumme, H. (2008). Immigrant families in Germany. Intergenerational solidarity in later life. Berlin: WeissenseeVerlag.

Beine, M., Docquier, F., \& Rapoport, H. (2008). Brain drain and human capital formation in developing countries: Winners and losers. Economic Journal, 118(528), 631-652.

Bolzman, C., Poncioni, R., Vial, M., \& Fibbi, R. (2004). Older labour migrants' wellbeing in Europe: The case of Switzerland. Ageing and Society, 24(3), 411-429.

Bolzman, C., Fibbi, R., \& Vial, M. (2006). What to do after retirement? Elderly migrants and the question of return. Journal of Ethnic and Migration Studies, 32(8), 1359-1375.

Colen, S. (1995). Like a mother to them: Stratified reproduction and West Indian childcare workers and employers in New York. In F. Ginsburg \& R. Rapp (Eds.), Conceiving the new world order: The global politics of reproduction (pp. 78-102). Oakland: University of California.

Collet, B., \& Santelli, E. (2012). Couples d'Ici, Parents d'ailleurs. Parcours de descendants d'immigrés. Paris: PUF Presses Universitaires de France.

Creese, G. (2011). The new African diaspora in Vancouver. Migration, exclusion and belonging. Toronto: University of Toronto Press.

Creese, G., Dyck, I., \& McLaren, A. (1999). Reconstituting the family: Negotiating immigration and settlement. Vancouver Centre of Excellence, RIIM Research on Immigration and Integration in the Metropolis, Working Paper Series, 99-10, 1-25.

Foner, N. (1997). The immigrant family: Cultural legacies and cultural changes. International Migration Review, 31(4), 961-974.

Foner, N. (Ed.). (2009). Across generations. New York: New York University Press.

Foner, N., \& Dreby, J. (2011). Relations between the generations in immigrant families. Annual Review of Sociology, 37, 545-564.

Ganga, D. (2006). From potential returnees into settlers: Nottingham's Older Italians. Journal of Ethnic and Migration Studies, 32(8), 1395-1413.

Gil Araujo, S. (2009). Family migration policies in Spain. NODE Policy Report. International Centre for Migration Policy Development. http://research.icmpd.org/1445.html. Accessed 12 Aug 2015.

Glick Schiller, N., \& Çaglar, A. (2008). "And ye shall possess it, and dwell therein": social citizenship, global Christianity and non-Ethnic immigrant incorporation. In D. Reed-Donahay \& C. Brettell (Eds.), Citizenship, political engagement and belonging: Immigrants in Europe and the United States (pp. 203-225). New Brunswick: Rutgers University Press.

Hansen, P. (2008). Circumcising migration: Gendering return migration among Somalilanders. Journal of Ethnic and Migration Studies, 34(7), 1109-1125. 
Itzigsohn, J., \& Giorguli-Saucedo, S. (2005). Incorporation, transnationalism, and gender: Immigrant incorporation and transnational participation as gendered processes. International Migration Review, 39(4), 895-920.

Journet, O., \& Julliard, A. (1994). Le Van des grands-mères. In C. Attias-Donfut \& L. Rosenmayr (Eds.), Vieillir en Afrique (pp. 191-212). Paris: PUF Presses Universitaires de France.

Kepel, G. (2011). Banlieue de la République. Paris: Institut Montaigne.

King, R., Christou, A., \& Teerling, J. (2011). "We took a bath with the chickens": Memories of childhood visits to the homeland by second-generation Greek and Greek Cypriot "returnees". Global Networks, 11(1), 1-23.

Kofman, E. (2004). Family-related migration: A critical review of European Studies. Journal of Ethnic and Migration Studies, 30(2), 243-262.

Kofman, E, \& Meetoo, V. (2008). Family migration. In World migration: Managing labour mobility in the evolving global economy (Vol. 4, pp. 151-172). IOM World Migration Report Series, Geneva.

Kohli, M. (1999). Private and public transfers between generations: Linking the family and the State. European Societies, 1(1), 81-104.

Levitt, P. (2009). Roots and routes: Understanding the lives of the second generation transnationally. Journal of Ethnic and Migration Studies, 35(7), 1225-1242.

Lockwood, D. (1996). Civic integration and class formation. British Journal of Sociology, 47(3), 531-550.

Maynard, M., Afshar, H., Franks, M., \& Wray, S. (2008). Women in later life: Exploring race and ethnicity. Maidenhead: Open University Press.

Morris, L. (2002). Managing migration: Civic stratification and migrants' rights. London: Routledge.

Nauck, B., \& Settles, B. (2001). Immigrant and ethnic minority families: An introduction. Journal of Comparative Family Studies, 32(4), 461-463.

Sayad, A. (1999). La double absence. Des illusions de l'émigré aux souffrances de l'immigré. Paris: Le Seuil.

Soysal, Y. N. (1994). Limits of citizenship. Migrants and postnational membership in Europe. Chicago: Chicago University Press.

United Nations. (2004). Human Development Report.

Waite, L., \& Cook, J. (2011). Belonging among diasporic African communities in the UK: Translocalism and plurilocal homelands. Emotion, Space and Society, 4(4), 238-248.

Wessendorf, S. (2007). Roots migrants: Transnationalism and 'return' among second-generation Italians in Switzerland. Journal of Ethnic and Migration Studies, 33(7), 1083-1102.

Open Access This chapter is licensed under the terms of the Creative Commons Attribution 4.0 International License (http://creativecommons.org/licenses/by/4.0/), which permits use, sharing, adaptation, distribution and reproduction in any medium or format, as long as you give appropriate credit to the original author(s) and the source, provide a link to the Creative Commons license and indicate if changes were made.

The images or other third party material in this chapter are included in the chapter's Creative Commons license, unless indicated otherwise in a credit line to the material. If material is not included in the chapter's Creative Commons license and your intended use is not permitted by statutory regulation or exceeds the permitted use, you will need to obtain permission directly from the copyright holder.

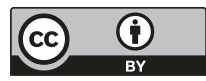

